\title{
Receiving spontaneous demand in Primary Care: nurses' learning needs
}

\author{
Acolhimento da demanda espontânea na Atenção Primária: necessidades de aprendizagem de enfermeiros \\ Recepción de la demanda espontanea en la atención primaria: necesidades de aprendizaje de enfermeiros
}

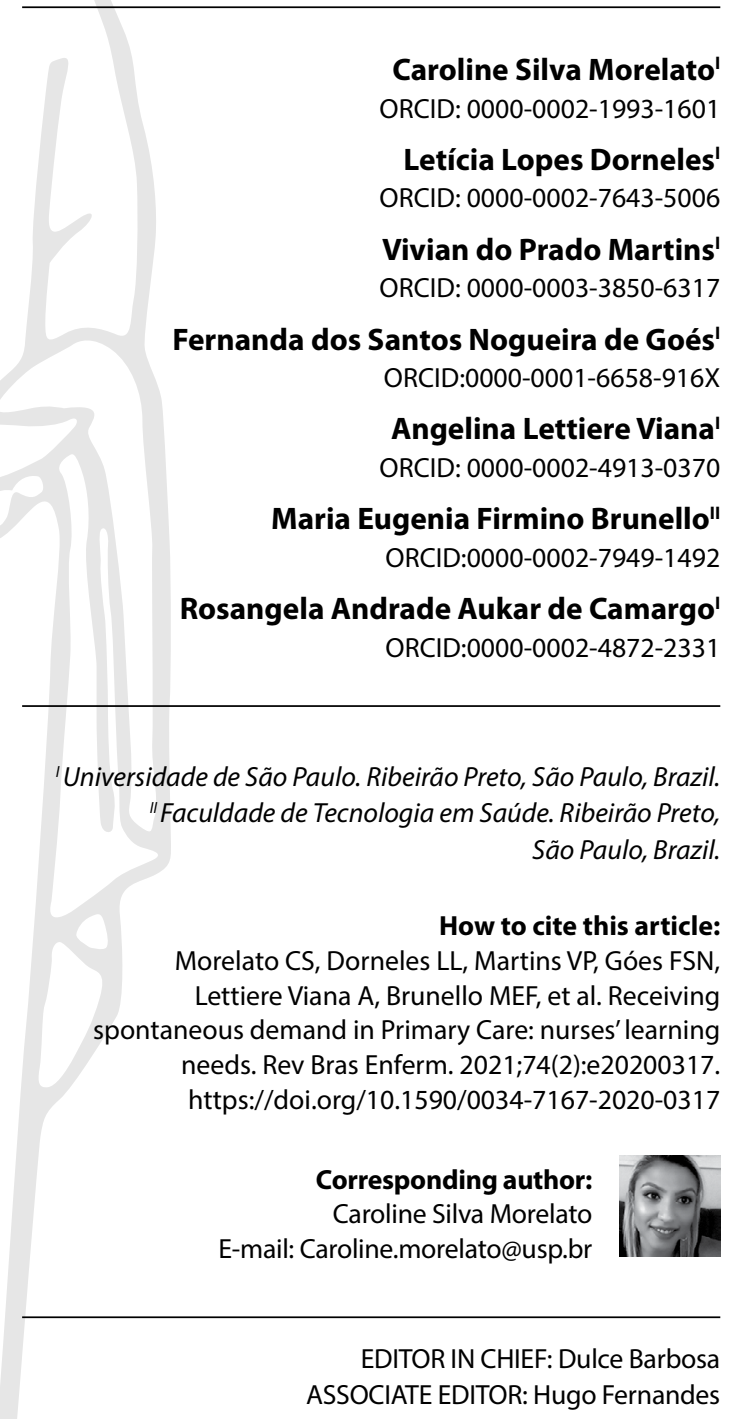

Submission: $04-20-2020$

Approval: 11-01-2020

\section{ABSTRACT}

Objective: Identify nurse's learning needs to be related to the reception with risk classification of spontaneous demand in Primary Health Care. Method: Quality study including 15 nurses from Primary Health Care through participatory observation, application of semi-structured instrument, focus group, and of thematic content analysis. Results: $80 \%$ of nurses never used the risk classification protocol in Primary Health Care. Knowledge gaps involving clinical aspects of care; protocol management, and the nurse's role; and the historic, structural and cultural contradictions of the care model were confirmed. Final considerations: The recognition of learning needs for nurses that work in Primary Health Care implies in the construction or improvement of knowledge in order to develop, along with the health team, a risk classification of spontaneous demand, which requires a change in the education and continuity of their qualification for work and at work.

Descriptors: Learning; Health Services Accessibility; Primary Health Care; Quality Assurance, Health Care; Education, Nursing.

\section{RESUMO}

Objetivo: Identificar necessidades de aprendizagem de enfermeiros sobre acolhimento com classificação de risco da demanda espontânea na Atenção Primária à Saúde (APS). Método: Estudo qualitativo realizado com 15 enfermeiros da Atenção Primária à Saúde por meio de observação participante, aplicação de instrumento semiestruturado, grupo focal e análise de conteúdo temática. Resultados: $80 \%$ dos enfermeiros nunca utilizaram o protocolo de classificação de risco na Atenção Primária à Saúde. Foram evidenciadas lacunas de conhecimento que envolvem os aspectos clínicos do cuidado; a gestão do protocolo e o papel do enfermeiro; e as contradições históricas, estruturais e culturais do modelo de cuidado. Considerações finais: $O$ reconhecimento das necessidades de aprendizagem dos enfermeiros atuantes na Atenção Primária à Saúde implica construção ou aprimoramento de saberes para desenvolver junto com a equipe de saúde a classificação de risco da demanda espontânea, o que requer a mudança na formação e a continuidade de sua qualificação no/para o trabalho.

Descritores: Aprendizagem; Acolhimento; Atenção Primária à Saúde; Humanização da Assistência; Educação em Enfermagem.

\section{RESUMEN}

Objetivo: Identificar necesidades de aprendizaje de enfermeros sobre recepción con clasificación de riesgo de la demanda espontanea en la Atención Primaria de Salud. Método: Estudio cualitativo realizado con 15 enfermeros de la Atención Primaria de Salud por medio de observación participante, aplicación de instrumento semiestructurado, equipo focal y análisis de contenido temático. Resultados: $80 \%$ de los enfermeros nunca utilizaron el protocolo de clasificación de riesgo en la Atención Primaria de Salud. Evidenciadas lagunas de conocimiento que envuelven los aspectos clínicos del cuidado; la gestión del protocolo y el papel del enfermero; y las contradicciones históricas, estructurales y culturales del modelo de cuidado. Consideraciones finales: El reconocimiento de necesidades de aprendizaje de los enfermeros actuantes en la Atención Primaria de Salud implica construcción o perfeccionamiento de saberes para desarrollar junto al equipo de salud la clasificación de riesgo de la demanda espontanea, el que requerir el cambio en la formación y la continuidad de su calificación en/para el trabajo.

Descriptores: Aprendizaje; Recepción; Atención Primaria de Salud; Humanización de la Asistencia; Educación en Enfermería. 


\section{INTRODUCTION}

The National Humanization Policy (PNH) of the Attention and Management of the Unified Health System - Humaniza SUS, is one of the ways which contributes to the workers' preparation ${ }^{(1)}$, similar to the Project for the Qualification of Care Practices, called AcolheSUS Project, acting at the entrance doors of SUS ${ }^{(2)}$; its planning is based on the following pillars: management and organization of care, the reception with risk and vulnerabilities evaluations, environment, and the professional training ${ }^{(1,3)}$. PNH also brings a new way of thinking about health ${ }^{(4)}$ to qualify the access and care practices through the introduction/implementation of the "Reception in health services" guidelines, which innovative ideas reduce barriers to access Primary Health Care $(\mathrm{PHC})^{(1)}$.

This study has a focus on the reception that should be performed by the workers of Health Basic Units (UBS), to ensure priority service when an evaluation for vulnerability, severity and risk is performed. For this purpose, PNH recommends the use of the Reception with risk classification (ACCR), through Manchester system, which purpose is order the services according to the risk potential, health problems or degree of suffering, prioritizing the most serious cases ${ }^{(5-7)}$. It starts with the identification of the main complaint expressed or related by the users and/or companions, based on the clinical risk, that is, it is proposed the performance of anamnesis and physical examination in the face of the expressed signs and symptoms, establishing the priority of care according to the conditions related to complications and risk of death ${ }^{(8)}$.

This classification is divided in at least four colors, which indicate maximum waiting time for the first attendance: red (emergency attendance), yellow (urgent attendance), green (less urgent attendance) and blue (not urgent attendance) ${ }^{(5)}$. In conclusion, ACCR represents a relational technological intervention device to enhance the reorganization of care and implement health production in Health Care Networks (RAS) in APS. Its goal is to provide a quick service, according to the users'risk and needs ${ }^{(5,9-10)}$. The use of Manchester System at UBSs and at Family Health Strategies (ESF), considered the SUS's entrance doors, may be adjusted to this level of attention and to the local situation ${ }^{(11)}$. It is worth to highlight that literature indicates safety, within ESF, as a parameter for defining clinical priorities using different classification flowcharts ${ }^{(12-13)}$.

The activation of ACCR will depend on the construction of a clinical, epidemic, and subjective knowledge, in the face of the multidisciplinary team's view regarding risks and vulnerabilities ${ }^{(11)}$. Within this scope, the nurse's work is highlighted, who is considered an indicated professional to evaluate and classify the severity of those who seek for health service ${ }^{(13-14)}$. For this purpose, their work at $\mathrm{PHC}$ has been requiring a continuous qualification process, that is, the need to absorb contents about their clinical, managing and educational practice in their daily life ${ }^{(15)}$. However, it is observed that nurses have difficulties to implement ACCR.

In this sense, one can ask: For the nurses working at PHC units, what are the learning needs to be related to ACCR of spontaneous demand? In order to answer this question, a literature review was carried out on the Health Virtual Library, with the descriptors and search strategy" Reception AND Classification AND Primary Health Attention" has identified 114 studies and, after the application of inclusion criteria (articles available in full, developed in Brazil, in
Portuguese language, and in the last ten years), 30 studies were selected. Only three of them ${ }^{(16-18)}$ addressed the Brazilian nurse work in ACCR within the $\mathrm{PHC}$, and reported the nurses' perceptions regarding $A C C R$, showing the structural and administrative difficulties for its operation. The first study, with 16 nurses from UBS and from Vale do Itajaí (SC), indicated that welcoming is summarized in the reception of the user, and that the nurse performs the reception with difficulty due to the excess of attributions and insecurity to make decisions, besides of the stigma of the medical society ${ }^{(16)}$. The second, also with 16 members of health teams from a UBS from the State of Parana, including nurses, analyzed that there is a lack of support from the coordination and of an appropriate physical structure for the ACCR, as well as insufficient knowledge about the subject ${ }^{(17)}$. The third, performed with nurses in a UBS from the city of Belo Horizonte (MG), showed the need for theory-practical articulation on $A_{C C R}{ }^{(18)}$. In fact, such surveys recognize the ACCR gaps in PHC and lack of nurses' qualification ${ }^{(16-18)}$, although in a generic way it is possibly related to the learning processes as at work. In this search, no studies were found that clearly addressed the nurses' learning needs to perform the ACCR for spontaneous demand. Therefore, this study is justified in view of the gap in scientific knowledge, because, although the topic is searched, it is observed that the learning needs were not explored.

\section{OBJECTIVE}

Identify nurses' learning needs to be related to the reception with risk classification of spontaneous demand in Primary Health Care.

\section{METHODS}

\section{Ethical aspects}

Survey approved by Committee on Ethics in Research of the Escola de Enfermagem of Ribeirão Preto; this is a clipping of Master's thesis entitled "Reception with risk classification of spontaneous demands: nurses' learning needs in Primary Health Care"(19).

\section{Type of study}

The study is characterized by a qualitative approach, with triangulation of data collection techniques ${ }^{(20)}$ and thematic content analysis $^{(21)}$.

\section{Study Setting}

The field of study was the Center for Permanent Education and Humanization (NEPH) of the Regional Health Department XIII - Ribeirão Preto, comprising 26 municipalities - With a monthly meetings, 38 interlocutors at the time of data collection (21 nurses, 2 community health workers, 2 psychologists, 3 social workers, 2 journalists, 2 university professors, 3 undergraduate students in Nursing, 2 masters students, 1 company administrator). Its current constitution remains unaltered, except for the undergraduate students: one of master's degree course and one of doctorate. The NEPH is a strategic collective space that allows the discussion of Humanization, Health Permanent Education (EPS), in addition 
to issues that involve the management to face local and regional problems, focused on the training of workers.

\section{Data Source}

Nurses that work in PHC for at least 6 months were intentionally included in this study and are interlocutors of their municipality in the $\mathrm{NEPH}$. From the 21 nurses, 3 were excluded for been working at NEPH recently, that is, they worked less than six months as interlocutors. From the 17 invited nurses to participate in the survey, 15 accepted.

\section{Collection and organization of data}

Collection of data was performed by the main researcher from June 2016 to Augusto 2017 in three stages, which were developed during the NEPH meetings. The first stage was performed during a meeting; the stages 2 and 3 were conducted after the end of the day's agenda.

In the first stage, there was a participatory observation in 12 meetings between June 2016 and May 2017 at NEPH, in order to know the background of the survey, bring participants closer to the researcher, as well as to concerns and issues related to the ACCR, which were registered in field diary and funded the construction of the semi-structured survey form with ten questions related to the nurse's work process in PHC and to the ACCR; this survey form was validated in form and in content by five specialists.

In the second stage, the semi-structured survey was applied in June 2017, regarding the Manchester Risk Rating System in order to identify the individual knowledge on AACR: knowledge and use in the professional practice of the nurse; examples of signs of alert that caused difficulties in classification by color; proceedings and guidelines adopted; individual understandings regarding the need of a new learning on the theme. The profile of the studied group was drawn (six questions).

And, finally, in the last stage, there was a focal group (GF) day in August 2017, in order to collectively understand the knowledge gaps in AACR, guided by the following question: What is the necessary learning the nurse needs to have to develop the ACCR in PHC? The GF, which lasted one hour and five minutes, was audio recorded and transcript. Coordinated by the main researcher, it counted on the support of the project's adviser as well as undergraduate research student, responsible by the annotations related to the relevant characteristics of the group. One guide with cases collected on ACCR during the meetings, served as an initial stimulus for the discussions, for example, the spontaneous seek for UBS by women with symptoms of urinary tract infection. Preparatory meetings between the main researcher and adviser preceded the realization of the GF, who are experienced in its development.

The Consolidated Criteria for Reporting Qualitative Research (COREQ) was used as criterion for the method description in the qualitative survey.

\section{Data Analysis}

In data processing, Bardin's content analysis technique ${ }^{(21)}$ was performed, a thematic mode with: a) analysis organization, previous analysis based on fluctuate reading of the material; $b$ ) codification - selection of documents and annotation of the essence of the messages by means of text clippings in comparable units; c) categorization, after in-depth study of the information set; d) treatment of results - inference and interpretation of results, which allowed the identification of the signification units when capturing the meanings of communications, content segments, that is, base units. Based on this process, the empiric material from the survey form and from GF was grouped by similarities and differences, making possible the immersion of the following thematic categories: the need for articulation of theoretical and practical knowledge about AACR; the need for comprehension the insertion and management of ACCR in PHC and the nurse role; the need for comprehension the contradictions that permeate the construction of the SUS care model.

The letter $E$ followed by Arabic numerals identified parts that originated the survey forms, whereas the letters GF, those from focal group. Lastly, the discussion of the results was reasoned on the Brazilian legal frameworks of Health and Education Policies, more specifically in PNH as a focus for the ACCR in PHC, and in the National Curricular Guidelines for the Nursing Undergraduate Courses (DNENF), since these concentrate the guiding principles of training for the nurse's work process in SUS.

\section{RESULTS}

\section{Profile of the respondents}

The respondents of the survey were 15 nurses; 13 (86.7\%) of them were female, with an average age of 39 years. The average length of experience in nursing was 12 years, 12 (80\%) worked exclusively in PHC, 2 (13.3\%) worked in PHC and in hospital, and 1 worked in PHC and in the education area, as a teacher, in a nursing technical course. In addition, 11 (73.3\%) had previously worked in Emergency Medical Unit, 12 (80.0\%) knew the Manchester protocol, however, they reported never having used it.

\section{The need for articulation of theoretical and practical knowledge about the Reception with risk classification in Primary Health Care}

This theory comprises individual deficiencies of the nurse/ respondent regarding the need to understand the ACCR protocol and regarding the lack of articulation of the previous knowledge for an appropriate clinical judgment during the ACCR of the spontaneous demand. Such need reaches the health teams management in the protocol implementation:

I need to learn the entire process related to reception. I never worked with it, and as little as I know, I have a lot of difficulties implementing it in the unit. (E6)

How to perform risk stratification properly and how to organize the health unit team. (E7)

Learning limitations most usually declared by the respondents, which involve alert signs and generate insecurity in red color ACCR, were as follows: sudden chest pain ( $<1$ hours) in hypertensive, 
diabetic and cardiac patients; headache or dizziness, change in vital signs; loss of strength, movement or sensitivity of part of the body and seizure. In yellow color, the cases were pregnant with any symptoms and fever (axillary temperature of $39^{\circ} \mathrm{C}$ ), green color to situations that involve chronic pain; and finally, blue color to issues or complaints lasting more than 15 days:

Pregnant woman with any symptom [...] depending on the situation, I have doubt if it's red, for example, when they allege bleeding. (E11)

Chronic pain with recent worsening, doubt remains in the yellow because patients often do not really report the need they are experiencing. (E11)

Identify if the lack of movement etc., are a consequence of a previous occurrence or if it is a current clinical situation. (E12)

\section{The need to understand the Reception with risk clas- sification management in Primary Health Care and the nurse's role}

The need to understand the ACCR management in PHC and its role in RAS is added to the doubts and insecurities related to the nurses' role, when they tell the activities performed in their daily routine and the conflicts lived more particularly with the physician in this context. Consequently, the knowledge gap regarding the Manchester Screening System in PHC causes distrust and fear that the programmatic actions already developed in UBSs and ESFs can be uncharacterized when absorbing spontaneous demand:

[...] the management required from us an adaptation of our work flow, the professionals were not able to stand it, because there was a fight among the professionals, I go to the nice doctor, he accepts, the bad one doesn't accept, everything is in the responsibility of nursing. (GF)

[...] if we don't have the teamwork, and we don't have [...] a protocol, it'll only work if we use it properly. (GF)

In the municipality, nurses [...] have many administrative actions; [...] and like punctual actions, making dressing, prenatal consultation, childcare. Beyond these tasks, we are "tight fit". (GF)

How to align the programmatic actions with the risk classification of acute cases, without allowing the reception of acute cases to transform UBS and ESF into a PA [Emergency Service]? (GF)

[...] I'm afraid the UBS is transformed in a big PA [...] it will not change the model, but change of address, PA in AB [Basic Care] [...]. (GF)

[...] when we put the initials $A B$ first, it deals with the patient integrality, that's why I think it's a little more complex, than classifying it in that color... we have the context. (GF)

\section{The need to understand the contradictions that permeate the construction of the SUS care model}

The need to understand historic and culture limits and advance in the change of the SUS care model work process, and the implementation of the ACCR originates from the reflection that the professionals carry out on the reality, from the conflict self-awareness that they experience in the model centered exclusively on the physician's decision, with the direct participation of the nurse to perpetuate it:

[...] As much as we want, as much as we talk, as much as we have units that work in a different way [...] the assistance model that we offer, it is still a model of assistance centered on physician professionals, "consultation", specialties, urgency and emergency. (GF)

[...] the daily life hinges on the time the doctor will be at the unit, everything that happens at the unit will depend on his availability, that is, the team, it works according to a reference person and not with the need in fact of the population. (GF)

[...] I think it needs a change on the care model [...] because we insist in working in the model centered in the physician [...] in the last 20 years, I helped educate the population to look for the doctor and look for the PA. (GF)

\section{DISCUSSION}

This survey identified the learning needs regarding the ACCR of spontaneous demand by nurses that work in PHC, both of individual and collective nature, which originate in knowledge gaps on: the clinical aspects that involve decision-making in the ACCR; the protocol management in PHC, and the nurse and the team's role in the work process in this context; and the historic, structural, and cultural contradictions of the care model proposed by SUS.

The respondent nurses of the survey had an average activity time in $\mathrm{PHC}$ of 12 years, similar number to the study that analyzed the perceptions of nurses regarding the reception in UBSs ${ }^{(22)}$. This information proves that those NEPH interlocutors nurses may have enough knowledge on the demands of their territory and on issues that involve management at this level of care, in addition to recognizing the possible weaknesses and potentials of the health team ${ }^{(15)}$. In conclusion, the profile of the respondents of this study proves the learning needs arose because they experience the problems of their municipalities directly in $\mathrm{PHC}$, and, at the same time, share a reflection space that allows the deepening of criticism and the exchange of experiences ${ }^{(22)}$.

Most part of the respondents worked in PA before $\mathrm{PHC}$, and although they know the Manchester protocol, $80 \%$ reported never used it in the professional practice. This information confirms the results of a study that revealed the difficulty of theoretical-practical articulation in the training of nurses, whose teaching remains in a fragmented logic between thinking and doing, distanced from the DCNs propositions for nursing courses, that is, these are based on criticality and scientific theories for reflective and conscious action ${ }^{(23)}$.

We evaluate that the first thematic category, as well as the others of this study that are discussed below, involve suppositions based on both the training of the generalist nurse and on the continuity of his qualification to/for the work. Notably, it is necessary the development of cognitive, procedural, and ethical and social skills, from the perspective of multidimensionality and indivisibility of the human being in health, compatible with the DCNs and with the main care demands of Primary Health Care ${ }^{(24-25)}$. 
The results show that the nurses have difficulties to understand the ACCR in PHC. The study that analyzed 246 curricula in the Nursing undergraduate course in Latin America identified 25 that included PHC in its structure, and the least emphasized contents were those involving skills in the complex decision-making, in practice based on evidences and in the understanding of the care context ${ }^{(26)}$. Another study analyzed the course syllabus of 94 Brazilian undergraduate courses and observed that they focus mainly in subjects of basic and vocational cycles, apart from the SUS program, although the Pedagogical Political Projects (PPP) confirms the integration of a pedagogical guidance and describes the curricular development by means of thematic axes/cores, in addition to valuing the fields of practice in UBSs and ESFs ${ }^{(27)}$. Another point is the continuation of a learning process deprived of meaning, reflection, autonomy, consequent of disassociation of knowledge, reception of information and memorization without its proper contextualization and questioning. It is about a mechanic learning that reproduce itself in the workspaces and hinder the clinical judgement and the decision-making, which depend on the critical thinking ${ }^{(28-29)}$.

In this survey, nurses show commitment and responsibility to the unit and try to be resourceful, but understand they are not skilled to make certain decisions that may entail risks to the clinical outcomes of PHC users. To some actions there are knowledge gaps that ratify the aforementioned studies when reflecting on the implications of training aligned with the propositions of the DCNs.

In the clinical training of nurse, the ACCR in PHC should occupy a central position ${ }^{(30-31)}$ so that care, in fact, fully meets the health-disease needs of the individual ${ }^{(32-33)}$. This reception has its scientific foundation in the nursing consultation, first stage of the Nursing Process (PE), the moment when the professional approaches the individual, listen to his demands, evaluate health, biopsychosocial and spiritual conditions and, lastly, plans the necessary care ${ }^{(34)}$.

However, when the respondents indicate the main signs of alert that generate difficulties in the moment of the classification, showed clinical unpreparedness in a decision-making. These limitations may entail several losses in the reception, as there is a risk of the professional only express the complaint behavior, without due reflection of the clinic for comprehensive care, valuing the work of the multidisciplinary and interdisciplinary team supported by the RAS ${ }^{(34)}$.

Therefore, it is crucial the use of the protocol to perform a qualified listening in order to avoid complaints and abbreviation of the user's autonomy ${ }^{(35)}$. The anamneses with physical exam in $P E$ are also critical, essential in the nurse's work process, for the implementation of the ACCR, as they seek: identify signs and symptoms, checking abnormalities that may suggest problems in the health and disease process; and plan not only curative, but also preventive ${ }^{(34)}$.

Since part of the nurses of this study does not know the ACCR protocol, it is understood that there may be a difficulty in organizing the work process in the face of the spontaneous demand, and still present solutions before situations, considering the integrality of care $\mathrm{PHC}^{(36)}$. That is, results show the need to understand the ACCR management in PHC, and essentially the nurse's role in this context that confirm the mismatch among the publication of a health policy, its dissemination, and its incorporation in the health units.

It is evident that the nurse needs to learn the flow organization of the health unit, having the unexpected demands, which happen and are inherent to the own life, as well as to know how to lead the team involvement in the ACCR with the Manchester protocol. It means develop skills to identify signs and symptoms that allows to substantiate the team actions and offer a scientific support to their possible decisions, as well as strengthen the ethical and social commitment because it builds a conscious and collective work process based on the principles that sustain the care in the network ${ }^{(6,28-29)}$.

The organization, from the perspective of receiving users, requires a reflection of the team on meeting community health needs, that is, user's profile and characteristics of the territory. It is important to create action in order the team can discuss the way each professional will participate in the reception, involving users, workers and managers, since the reception is not based on a separate character ${ }^{(35)}$.

The unforeseen situations require a type of organization of the unit and of the teamwork, both to understand them and to intervene on them. In these cases, workers in charge of listen to the demands arose spontaneously (without a previous appointment) must have: ability to analyze them (identifying risks and analyzing vulnerabilities); clarify the care offers available at UBS; a possible dialog among colleagues; any kind of resourcefulness and support to request care offers in times and ways that they consider people's needs ${ }^{(14)}$.

The knowledge gaps on ACCR management show the need for $\mathrm{PHC}$ nurses to understand their roles in this context, and the ethical and legal aspects that guide the profession, considered a wide field and in process of qualification, both in clinical practice and in individual and collective educational performance or even in management operational ${ }^{(15)}$. Legally, in order to put into effect the National Primary Care Policy, (PNAB), according to the Ordinance 2,436/2017 of Ministry of Health, the specific duties of the nurses are the performance and/or supervision of the reception with qualified listening and risk classification, according to the established protocols; performance of stratification of risk and elaboration of care plans intended to people with chronic conditions in the territory, along with the other members of the team; implementation and maintenance of routines, protocols and flows updated in relation to their area of competence at UBS ${ }^{(36)}$.

Such attributions expand the nurse autonomy when developing a clinical practice that assume the integrality of care to families and communities in all their life cycle. It implies that a nurse has mastery of several skills, such as: managing of his work process, clinical and abstract reasoning, planning, communication, time administration, technical-scientific knowledge of the area (child health, women health, contagious infectious diseases, pregnancy, immunization, mental health, care for skin lesions, hypertension, diabetes, among many others) ${ }^{(22,37-38)}$.

The reception of the population in $\mathrm{PHC}$ by nurses has a facilitating and more resourceful action of healthcare when prioritizing attendance to acute events, also recommended by the $\mathrm{PNH}$, in the Reception Booklet with Risk Assessment and Classification (In Portuguese, "Cartilha de Acolhimento com Avaliação e 
Classificação de Risco"), published by the Health Ministry. Such attributions have also legal support by the Law of Professional Nursing Practice. A study that described the implementation of the reception Project with risk classification in a UBS in Brasilia indicated an increase of $193.7 \%$ in nursing checks for patients classified by green color, which presented acute conditions, but without imminent risk of worsening condition, after training the protocol proposed by the Health Ministry ${ }^{(1)}$.

Recently, nurses from this study assume that the management of the unit and the punctual actions are their attributions, and they find it difficult to advance in PHC purposes. When the term "tight fit" is used, one reveals that he is tight to a process in which attributions and responsibilities listed above are poorly discussed; and, mistakenly, such professionals understand that the disease prevention and health promotion programs should not be overtaken by the spontaneous demand in UBS or ESF because it would transform the place as a PA. However, the value of this study that the respondents attribute to the integrality of care is not linked to the attributes of the PHC and to the knowledge of the actions that operationalize them in the health units ${ }^{(33)}$. With good reason, they value humanized care, but without grounds.

A qualitative study that evaluated the effectiveness of $\mathrm{PHC}$ attributes in the perspective of professionals and users, indicated that the best results were the first contact and integrality, which confirms the PHC gradual legitimation as a gateway service accessible in RAS, with a diversified scope of actions, although insufficient. The worst rated attributes were: longitudinality, with low continuity and quality of the professional-patient relationship; and the coordination, due to difficulties in accessing specialized consultations and insufficient shared records ${ }^{(39)}$.

Despite the advances, the $\mathrm{PHC}$ as a gateway still concentrates contradictions in its flow, which is evident in the confrontation between individual demands and the services offered, in the degree of resolvability, in interpersonal relationships and technological density. On the other hand, the seek for the PA represents the immediate consultations, procedures, complementary exams, medication acquisition, and hospitalization, if necessary ${ }^{(40-42)}$.

These contradictions were also found in this study when nurses showed concern with the unit flow in the implementation of ACCR and lack of knowledge on the use of the care integrality principle in spontaneous demand. This fact occurs because the treatment of acute situations is rooted to the complaint/conduct dynamic, which could deconstruct legitimate preventive actions in the health unit in its territory. However, these situations that can guide and qualify the assistance advances in UBSs and FHS, as in case of people with diabetes and arterial hypertension, in addition to anticipating the possibility of intervention in outbreaks that have epidemiological relevance ${ }^{(43)}$.

The need to have a better understanding and operationalization of the spontaneous demand flow is linked to the need to recognize the historic and cultural limits of the change process of the SUS care model ${ }^{(44)}$. It is due because the demands are still centered in the curativist model and centralized in the physician and, the population understands that the access to the health system means access to the physician ${ }^{(11)}$. This survey reaffirms this practice, when all the respondents recognize that the medical consultation is still the center of the work process in most of the municipalities, situation that is perpetuated with the direct participation of the nurse as the spontaneous demand has become a negotiation dependent on the physician's understanding of the ACCR. This reality generates a lack of autonomy and insecurity in the health team since the clinical care is resumed to a single professional category. In addition, this study endorses the position that limited consultation fees generate various discomforts and the lack of guarantee of access to care, which is against the principle of equity, which consist in providing care differently to the unequal, according to each need during the reception ${ }^{(45)}$.

In this perspective, it is importance to prioritize service in some cases in order to avoid keeping the suffering person waiting for a long time ${ }^{(45)}$. Such challenges may be faced by means of the valuation of the nurse's clinical skill, implementation of a participative management that involves local collegiate bodies, qualification of the professionals in their work through a permanent training and maintenance of adequate proportions of population outlined by team ${ }^{(45-46)}$. However, managing barriers are reported, in literature, as a shortage of human resources with work overload of the team's professionals, and even in the ACCR training ${ }^{(43)}$.

In such context, these barriers also enhance the traditional care model, precluding a higher autonomy of the nursing team: they make persist the curativist clinical logic, physician-centered, regardless the insertion of a protocol such as the ACCR or not. The pointed perspectives confirm another issue indicated by the respondents, the $\mathrm{PHC}$ depreciation, that is, when the population cannot have the prompt service, they seek for a faster and "facilitated" service, such as the PA or pharmacy services. These facts converge with the findings of another study in which the health users seek for the PA as a regular source of care and expose failures in the access and reception of services in the primary level ${ }^{(47)}$.

Despite the advances in the health policy in Brazil, related to the positive sanitary results with the expansion of specific programs and public services, it is noted that historic-structural limits and the outstanding social stratification in a Capitalist State, where the laws of the market are in force, delay or withhold the transformations necessary to consolidation of an assistance model based on the SUS doctrinal principles ${ }^{(48)}$. Surprisingly, the respondents of this study perceive the need to change the model, which means understand the Brazilian democracy context and the value attributed to health in the National, Regional, and Municipal macro/micro politics.

Lastly, all needs highlighted implies in the planning of educational actions that are recommended by the National Policy of Permanent Education in Health (PNEPS) and by the $\mathrm{PNH}^{(49)}$. Such action must work PHC daily life, since any and all demand for changes and adaptations of health policies and programs depend on the previous professional qualification and of a continued reflection of the produced acts ${ }^{(1)}$.

\section{Study limitations}

Limitation is considered as the perception of the object of study by the nurses' view only. There is a need to develop surveys that include all the PHC health team, in order to prove the implications of the ACCR Protocol in the daily life of the health unit. 


\section{Contributions for nursing and public health areas}

This study, in an effort to try to understand the gaps of knowledge about the ACCR of the nurse working in $\mathrm{PHC}$, indicates the need to review the training of this professional for the improvement of assistance and management skills, both in undergraduate course and at work, since the learning needs identified involve higher efficiency in the development of SAE and in the management of work process in SUS.

\section{FINAL CONSIDERATIONS}

At the end of this survey, it is concluded that the knowledge gaps exposed through the understanding of learning needs regarding the ACCR by nurses that work in PHC involve knowledge related to clinical practice, $\mathrm{PNH}$, basic attention management, health model recommended by SUS, and to the nurse's own role in this context. The learning needs emerged in the results of this survey reveal once again the paradox of the changes historically built in the context of SUS that are still permeated by the rooted practices of the model focused on the physician. Ambiguities surrounding the ACCR in PHC were identified, as the strategy would plaster all the assistance practice that characterizes this level of attention and interrupt the daily activities. It also found the respondent's demand for theoretical and practical knowledge about the Manchester protocol to advance the implementation of the ACCR of spontaneous demand, without disregarding other policies and the PHC context itself. It is Worth to mention that, beyond the direct assistance to users and to $A C C R$, it is up to the professional nurses strengthen their competences, professional and community management and education activities, practicing a range of interfaces that form care. The gaps in professional education related to these aspects, reflect in difficulties in the practice of nurses when inserted in the market, underutilizing their management and decision-making skills. Lastly, the importance of EPS stands out within the health units for strengthening the practice of ACCR and SUS. This work pointed out issues that may serve as subsidies for reflection on the organization of care practices in health services.

\section{FUNDING}

This survey was founded by the UNIVERSAL/CNPq project.

\section{REFERENCES}

1. Martins ACT, Paula AP, Cardoso JR, Borges MIG, Botelho MB. O Projeto AcolheSUS na Atenção Primária à Saúde do Distrito Federal, Brasil. Ciênc Saúde Coletiva. 2019;24(6):2095-103. https://doi.org/10.1590/1413-81232018246.08492019

2. Menezes ELC, Verdi MIM, Scherer MDA, Finkler M. Modos de produção do cuidado e a universalidade do acesso: análise de orientações federais para o trabalho das equipes da APS no Brasil. Ciênc Saúde Coletiva . 2020;25(5):1751-64. https://doi. org/10.1590/1413-81232020255.33462019

3. Ministério da Saúde (BR). Acolhimento na gestão e o trabalho em saúde [Internet]. Brasília: Ministério da Saúde; 2016 [cited 2020 Jan 22]. Available from: http://bvsms.saude.gov.br/bvs/publicacoes/acolhimento_gestao_trabalho_saude.pdf.

4. Reis-Borges GC, Nascimento EM, Borges DM. Impact of National Humanization Policy in the Family Health Strategy. Distúrb Comun. 2018;30(1):194-200. https://doi.org/10.23925/2176-2724.2018v30i1p194-200

5. Ministério da Saúde (BR). Secretaria Executiva. Núcleo Técnico da Política Nacional de Humanização. Humaniza SUS: acolhimento com avaliação e classificação de risco: um paradigma ético-estético no fazer em saúde [Internet]. Brasília: Ministério da Saúde; 2004 [cited 2020 Jan 22]. Available from: http://bvsms.saude.gov.br/bvs/publicacoes/acolhimento.pdf

6. Mackway-Jones K, Marsden J, Windle J. Emergency triage: Manchester Triage Group. 3rd ed. Hoboken: Wiley-Blackwell; 2014.

7. Ministério da Saúde (BR). Secretaria Executiva. Núcleo Técnico da Política Nacional de Humanização da Atenção e Gestão do SUS. Acolhimento e classificação de risco nos serviços de Urgência [Internet]. Brasília: Ministério da Saúde; 2009 [cited 2020 Jan 22]. Available from: http://bvsms.saude.gov.br/bvs/publicacoes/acolhimento_classificaao_risco_servico_urgencia.pdf.

8. Magalhães-Barbosa MC, Prata-Barbosa A, Cunha AJLA, Lopes CS. CLARIPED: a new tool for risk classification in pediatric emergencies. Rev Paul Pediatr. 2016;34(3):254-62. doi: 10.1016/j.rppede.2016.02.002

9. Guedes HM, Souza CC, Pinto Jr D, Morais SS, Chianca TCM. Evaluation of vital signs by the Manchester triage system: expert agreement. Rev Enferm UERJ. 2017;25:e7506. https://doi.org/10.12957/reuerj.2017.7506

10. Ministério da Saúde (BR). Secretaria de Atenção à Saúde. Política Nacional de Humanização da Atenção e Gestão do SUS. Clínica ampliada e compartilhada [Internet]. Brasília: Ministério da Saúde; 2009 [cited 2020 Jan 22]. Available from: http://bvsms.saude.gov.br/bvs/publicacoes/ clinica_ampliada_compartilhada.pdf

11. Ministério da Saúde (BR). Secretaria de Atenção à Saúde. Departamento de Atenção Básica. Acolhimento à demanda espontânea [Internet]. Brasília: Ministério da Saúde; 2013 [cited 2020 Jan 22]. Available from: http://bvsms.saude.gov.br/bvs/publicacoes/acolhimento_demanda_ espontanea_cab28v1.pdf

12. Souza CC, Chianca TCM, Cordeiro Júnior W, Rausch MCP, Nascimento GFL. Reliability analysis of the Manchester Triage System: interobserver and intra-observer agreement. Rev Latino-Am Enfermagem. 2018;26:e3005. doi: 10.1590/1518-8345.2205.3005

13. Lacerda ASB, Sauthier M, Paes GO, Teixeira ER. Embracement with risk classification: relationship of justice with the user. Rev Bras Enferm. 2019;72(6):1496-503. https://doi.org/10.1590/0034-7167-2018-0420 
14. Roncalli AA, Oliveira DN, Silva ICM, Brito RF, Viegas SMF. Manchester Protocol and user population in the risk assessment: the nurse's view. Rev Baiana Enferm. 2017;31(2):e16949. https://doi.org/10.18471/rbe.v31i2.16949

15. Ferreira SRS, Périco LAD, Dias VRFG. A complexidade do trabalho do enfermeiro na Atenção Básica à Saúde. Rev Bras Enferm. 2018;71(Suplemento1):704-9. https://doi.org/10.1590/0034-7167-2017-0471

16. Costa AB, Gouvea PB, Rangel RCT, Scnheider P, Alves TF, Acosta AS. [Nurses' perception of embracement and risk classification in Primary Health Care]. Enferm Actual Costa Rica. 2018;(35):103-115. https://doi.org/10.15517/revenf.v0i35.32113 Spanish.

17. Rocha NB, Franchin AT, Gasparetto A, Lollj LF, Fujimaki M. [Knowledge about user embracement with risk classification by the Primary Care team] Espac Saúde [Internet]. 2017[cited 2020 Jan 22];18(1):72-80. Available from: https://pesquisa.bvsalud.org/portal/resource/pt/biblio-848328 Portuguese.

18. Silva PM, Barros KP, Torres HC. Nurses' perception on hospital welcoming classified as Primary Health Care risk. Rev Min Enferm[Internet]. 2012 [cited 2020 Jan 22];16(2):225-31. Available from: http://www.reme.org.br/artigo/detalhes/523\#

19. Coloni CSM. Host classification of the spontaneous demand risk: the learning needs of nurses from primary health care [Dissertação]. 2018. https://doi.org/10.11606/D.22.2019.tde-29012019-104439

20. Creswell J. Research Design: qualitative and quantitative approaches. 5th ed. California: Sage Publications; 2018.

21. Bardin L. Análise de conteúdo. 4a ed. Lisboa: Almedina; 2011.

22. Camelo MS, Lima LR, Volpe CRG, Santos WS, Rehem TCMSB. Welcoming in primary health care from the viewpoint of nurses. Acta Paul Enferm. 2016;29(4):463-8. https://doi.org/10.1590/1982-0194201600063

23. Oliveira VAC, Gazzinelli MF, Oliveira PP. Theoretical-practical articulation in a curriculum of a Nursing course. Esc Anna Nery. 2020;24(3):e20190301. https://doi.org/10.1590/2177-9465-ean-2019-0301.

24. Magnago C, Pierantoni CR. Nursing training and their approximation to the assumptions of the National Curriculum Guidelines and Primary Health Care. Ciênc Saúde Colet. 2020;25(1):15-24. https://doi.org/10.1590/1413-81232020251.28372019

25. Arantes MM, Ferreira AL. Reflections on the integral human being and the conception of health. Rev Enferm Dig Cuid Prom Saúde. 2019;4(2):140-5. https://doi.org/10.5935/2446-5682.20190023

26. Cassiani SHB, Wilson LL, Mikael SSE, Pena LM, Grajales RAZ, McCreary LL, et al. The situation of nursing education in Latin America and the Caribbean towards universal health. Rev Latino-Am Enferm. 2017;25:e2913. https://doi.org/10.1590/1518-8345.2232.2913

27. Berndtsson I, Dahlborg E, Pennbrant S. Work-integrated learning as a pedagogical tool to integrate theory and practice in nursing education: an integrative literature review. Nurse Educ Pract. 2019;42:102685. https://doi.org/10.1016/j.nepr.2019.102685

28. Jayasekara R, Smith C, Hall C, Rankin E, Smith M, Visvanathan V, et al. The effectiveness of clinical education models for undergraduate nursing programs: a systematic review. Nurse Educ Pract. 2018;29:116-126. https://doi.org/10.1016/j.nepr.2017.12.006

29. Ortega MdCB, Cecagno D, Llor AMS, Siqueira HCH, Montesinos MJL, Soler LM. Academic training of nursing professionals and its relevance to the workplace. Rev Latino-Am Enferm. 2015;23(3):404-10. https://doi.org/10.1590/0104-1169.0432.2569

30. Cassiani SHB, Aguirre-Boza F, Hoyos MC, Barreto MFC, Peña LM, Mackay MCC, et al. Competencies for training advanced practice nurses in primary health care. Acta Paul Enferm. 2018;31(6):572-84. https://doi.org/10.1590/1982-0194201800080

31. Silveira LC, Vieira AN, Monteiro ARM, Miranda KCL, Silva LF. Clinical care in nursing: development of a concept in the perspective of professional practice reconstruction. Esc Anna Nery. 2013;17(3):548-54. https://doi.org/10.1590/S1414-81452013000300020

32. Clark M, Raffray M, Hendricks K, Gagnon AJ. Global and public health core competencies for nursing education: a systematic review of essential competencies. Nurse Educ Today. 2016;40:173-80. https://doi.org/10.1016/j.nedt.2016.02.026

33. Acioli S, Kebian LVA, Faria MGA, Ferracioli P, Correa VAF. Care practices: the role of nurses in primary health care. Rev Enferm UERJ. 2014;22(5):637-42. https://doi.org/10.12957/reuerj.2014.12338

34. Hino P, Horta ALM, Gamba MA, Taminato M, Fernandes H, Sala DCP. Comprehensiveness in the perspective of public health: pathways for the training of the nurse. Rev Bras Enferm. 2019;72(4):1119-23. https://doi.org/10.1590/0034-7167-2018-0443

35. Rossato K, Real VR, Buligon GO Araujo CDC. Reception with risk rating in the family health strategy: perception of the nursing team. Rev Enferm UFSM. 2018;8(1):144-56. https://doi.org/10.5902/2179769226655

36. Ministério da Saúde (BR). Portaria n 5, de 28 de setembro de 2017. Consolidação das normas sobre as ações e os serviços de saúde do Sistema Único de Saúde. Gabinete do ministério. 28 de setembro de 2017.

37. Dunbar SSS. Consistency in grading clinical skills. Nurse Educ Pract. 2018;31:136-142. https://doi.org/10.1016/j.nepr.2018.05.013

38. Krauzer IM, Adamy EK, Ascari RA, Ferraz L, Trindade LL, Neiss M. Nursing care systematization in primary care: what do the nurses say? Cienc Enferm [Internet]. 2015 [cited 2019 Dec 20];XXI(2):31-38. Available from: https://scielo.conicyt.cl/pdf/cienf/v21n2/art_04.pdf

39. Lima JG, Giovanella L, Fausto MCR, Bousquat A, Silva EV. Essential attributes of Primary Health Care: national results of PMAQ-AB. Saúde Debate. 2018;42(1):52-66. https://doi.org/10.1598/0103-11042018s104

40. Oliveira MADC, Pereira IC. Primary Health Care essential attributes and the Family Health Strategy. Rev Bras Enferm. 2013;66(esp):158-164. https://doi.org/10.1590/S0034-71672013000700020

41. Campos RTO, Ferrer AL, Gama CAPD, Campos GWDS, Trapé TL, Dantas DV. [Assesment of quality of access in primary care in a large Brazilian city in the perspective of users]. Saúde Debate. 2014;38(esp):252-264. https://doi.org/10.5935/0103-1104.2014S019. Portuguese. 
42. Rati RMS, Goulart LMHF, Alvim CG, Mota JAC. ["Children cannot wait": why mothers seek urgency and emergency care services for their children in non-urgent situations]. Ciênc Saúde Colet. 2013 Dec;18(12):3663-3672. https://doi.org/10.1590/S1413-81232013001200022 Portuguese.

43. Salci MA, Meirelles BHS, Silva DMGV. Primary care for diabetes mellitus patients from the perspective of the care model for chronic conditions. Rev Latino-Am Enferm. 2017;25:e2882. https://doi.org/10.1590/1518-8345.1474.2882

44. Campos KFC, Marques RC, Ceccim, RB, Silva, KL. [Permanent health education and care model: correlations in the daily routine of Primary Health Care]. APS Rev. 2019;1(2):132-40. https://doi.org/10.14295/aps.v1i2.28 Portuguese.

45. Santos RR, Lima EDFA, Freitas PDSS, Galavote HS, Rocha EMS, Lima RDCD. [The role of teamwork in Primary Health Care]. Rev Bras Pesqui Saúde. 2016;18(1):130-9. https://doi.org/10.21722/rbps.v18i1.15144 Portuguese.

46. Cassettari SDSR, Mello ALSF. Demand and type of care provided in emergency services in the city of Florianópolis, Brazil. Texto Contexto Enferm. 2017;26(1):e3400015. https://doi.org/10.1590/0104-07072017003400015

47. Gomide M, Pinto I, Zacharias F, Ferro D. [Analysis of access and care among PMAQ-AB results and users satisfaction of emergency department: similarities and diferences]. Medicina (Ribeirão Preto). 2017;50(1);29-38. https://doi.org/10.11606/issn.2176-7262.v50i1 p29-38 Portuguese.

48. Machado CV, Lima LD, Baptista TWF. Health policies in Brazil in times of contradiction: paths and pitfalls in the construction of a universal system. Cad Saúde Pública. 2017;33(Suppl 2):e00129616. https://doi.org/10.1590/0102-311X00129616

49. Vasconcelos MFF, Nicolotti CA, Silva JF, Pereira SMLR. In-between policies (CEH - Continuing Education in Health and NHP - Humanization National Policy): towards a way to educate in/for the Brazilian National Health System (SUS). Interface (Botucatu). 2016;20(59):981-91. https://doi.org/10.1590/1807-57622015.0707 